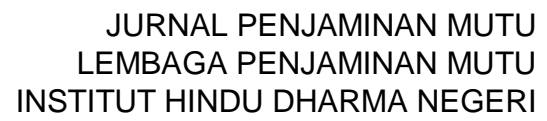

JURNAL PENJAMINAN MUTU

LEMBAGA PENJAMINAN MUTU

INSTITUT HINDU DHARMA NEGERI

DENPASAR
Volume 6 Nomor 1 (2020)

ISSN : 2407-912X (Cetak)

ISSN : 2548-3110 (Online)

http://ejournal.ihdn.ac.id/index.php/JPM

\title{
IMPLEMENTATION OF TRI HITA KARANA TEACHING TO FORM STUDENTS CHARACTERS QUALITY
}

\author{
By \\ I Wayan Mandra ${ }^{1}$, Dhammananda ${ }^{2}$ \\ ${ }^{1}$ Universitas Hindu Negeri I Gusti Bagus Sugriwa Denpasar \\ ${ }^{2}$ Sekolah Tinggi Agama Hindu Gde Pudja Mataram \\ ${ }^{1}$ wayanmandraihdn@gmail.com
}

diterima 19 Oktober 2019, direvisi 17 Januari 2020, diterbitkan 29 Pebruari 2020

\begin{abstract}
Abstrak
Tri Hita Karana di lingkungan sekolah dasar merupakan upaya dalam pembelajaran agama Hindu dalam mengembangkan ke tiga aspek yaitu kognitif, afektif dan psikomotor. Melalui Pendidikan Agama siswa Agama Hindu dibimbing agar selalu membina hubungan yang harmonis dengan Tuhan, sesama dan dengan lingkungan. Ajaran Tri Hita Karana akan terwujud melalui keseimbangan dalam pelaksanaannya dalam menjaga hubungan yang harmonis antara manusia dengan Tuhan, manusia dengan sesamanya, dan manusia dengan alam lingkungannya. Dari pengamatan awal terdapat beberapa jenis pelanggaran atau penyimpangan perilaku siswa yang cenderung negatif antara lain perilaku siswa yang kurang hormat kepada guru, melawan atau menentang nasehat guru, siswa yang selalu bercanda saat melaksanakan tri sandya, ada beberapa siswa yang kurang aktif dalam kegiatan kerja bakti dengan lebih banyak mengobrol atau menjauh saat teman temannya bergotong royong untuk membersihkan lingkungan sekolah, dan ada beberapa siswa yang terlihat lebih suka membuang sampah sembarangan di ruang kelas atau di halaman sekolah.
\end{abstract}

\section{Kata Kunci : Karakter; Tri Hita Karana; Agama Hindu}

\begin{abstract}
Tri Hita Karana at the elementary school environment is an effort in learning Hinduism to develop three aspects, namely cognitive, affective and psychomotor. Through religious education, Hindu Religion students are guided to always foster harmonious relations with God, others and the environment. Tri Hita Karana's teachings will be realized through balance in their implementation to maintain a harmonious relationship between humans and God, humans with each other, and humans with the natural environment. From preliminary observations, there are several types of violations or deviations of student behavior that are negative, including the behavior of students who are less obedient to the teacher, rebel or against the teacher's advice, students who are always joking when carrying out tri-sandya, some students who are less
\end{abstract}


active in community service activities and have more chat or stay away when friends work together to clean up the school environment, and some students who seem to prefer littering in the classroom or the schoolyard.

\section{Keywords: Character; Tri Hita Karana; Hinduism}

\section{INTRODUCTION}

The island of Bali is known as the island of a thousand temples in the Republic's territory of Indonesia where most of the population is Hindu. The island of Bali is already famous for its famous tourist areas throughout the world Bali is known as a region with world-wide cultural richness. In addition to traditional arts, a variety of rituals and religious ceremonies also become an attraction of this region. As is well known that the majority of people in Bali embraced Hinduism and upheld the beliefs and values inherited from generation to generation (Sartika \& Joebagyo, 2020). Many tourists are from abroad and within the country who visited Bali. This makes a very rapid development because the demands and needs of humans are increasing. Development in all sectors in Bali which has not and has yet to be met requires special limitations and attention from all parties concerned, to avoid irregular spatial planning, especially in environmental management. According to Law No. 4 of 1982 about Hindu environment by the environment is the unity of space with all objects, power, conditions and living things, including human beings and their behavior that affect the continuity of life and welfare of humans and other living things (Sarwono, 1995).

It divides natural resources are into renewable natural resources (such as forests, agriculture, fisheries). Non-renewable natural resources (such as oil, coal, gas). From the point of use of non-renewable natural resources, they must manage it according to a pattern that respects the preservation of nature (Salim, 1986). So, as an agent of development, necessary to understand that the development activities are managing natural resources and managing the environment. The negative impact of this change can break the chains in various cycles that live in ecosystems, thus disrupting human harmony with the environment. School is a place where formal education takes place, a place for students to study. We expect education to contribute positively to students and the community as a recipient of output from the educational process. According to Harianti \& Amin, parenting patterns can have an impact on a child's motivation to learn. The nature of the parents, how family management, and family conflict can have an impact on children's motivation in learning (Sukmaningrum \& Faizah, 2019). Education takes place well when educators and students seek good learning conditions and can give and take from one another in the learning process, two-way communication occurs between the teacher and student. One effort in creating students on national education goals from elementary schools to higher education by providing religious education in schools that play a role in shaping student character.

Tri Hita Karana is an element of Balinese culture that was inherited from generation to generation in desa pakraman and their functional until now. It literally comes from the words "tri" means three, " hita" means a welfare, and "karana" means the cause. It is understood by Hindus in Bali to three causes to be a welfare. Therefore, Tri Hita Karana concepts are illustrated as the cause and effect. Thus, in addition to consist of a welfare cause, as well as it illustrates a esult, welfare purposes. Not only cause and effect, but also the process of a welfare achievement through dynamic interaction with the three elements, related in "harmonious" inside and among parhyangan, pawongan, and palemahan (Sukarma, 2016).

For this reason, the education of character values and spirituality at school is 
best taught through implementing the concept of the Tri Hita Karana teachings, because the teachings of Tri Hita Karana develop an attitude of life that is balanced and harmonious with God, with fellow human beings, and with the natural environment, thus creating a happy life (Wiana, 2007). When a harmonious and happy life becomes a life activity, then it will be continuously pursued and the harmonious relationship will truly be integrated actively. The concept of Tri Hita Karana is grouped into three values, namely: (1) A harmonious relationship with God Almighty (Parhyangan), (2) A harmonious relationship with fellow human beings (Pawongan), (3) A harmonious relationship with the natural environment ( Palemahan) the concept of Tri Hita Karana teachings introduces the values of the reality of living together to inculcate religious values, civilizing social values, gender appreciation, planting values of justice, developing democratic attitudes, instilling honest attitudes, and taking responsibility and respect for the natural environment (Donder, 2007). In the process of education, implementing the concept of Tri Hita Karana can influence learning outcomes, because one concept of Tri Hita Karana which is to maintain harmony with others will be more obedient to school rules, increase respect for teachers or older people, foster a sense of devotion to God Almighty and have a sense of caring for the environment.

\section{METHOD}

The research method was an attempt to find, develop and study the truth of knowledge. The method is not only used as a tool to draw conclusions, explain and analyze problems, but is also used to solve problems. Theories used to solve these problems are structural-functional theory and value theory. The method used for data collection includes observation, interviews, literature, documentation. It processed all data using qualitative descriptive techniques.

\section{RESULTS AND DISCUSSION}

Collaboration between school and family needs to be increased so that there are no contradictions or inconsistencies between the values that children in schools must hold and those they must follow in the family environment or in the community where the child is. If there is a conflict of values, children may feel confused so they do not have a reference on the values to behave. As a result, they cannot control themselves in facing negative influences from the surrounding environment.

Indonesian young people who commit delinquency as explained, indeed in quite high numbers. Most of these young people deal with minor violations such as theft, truancy, robbery, and pursuit, or other more serious violations such as Ms. Drugs, violence and murder. These young people need social care and education in prisons, otherwise it can lead to more offensive behavior and lead to a decline in lifelong health (Rosmilawati \& Darmawan, 2019).

The pattern of partnerships carried out by teachers in schools with parents of students would be effective, in the education's context of character values and spirituality for students at school? The partnership needed is not formal in the form of signing an agreement or something similar, but which naturally and continuously can unite the steps in educating the sons and daughters of the Indonesian nation. Creating an atmosphere conducive to the education of character values and spirituality, both at school and home, seems to be one form of partnership that needs to be developed by teachers in schools with parents of students (Zuchdi, 2011). The atmosphere of life at school and home influences the development of the child's personality, because it is a vehicle to seed the values that will be a reference by students/children in every action. If students feel at ease in school, so too when staying at home, they can enjoy working together with peers to achieve shared learning progress. These values are a prerequisite for the building of a generation of intelligent and noble, advanced and peaceful (Zuchdi, 2011). 


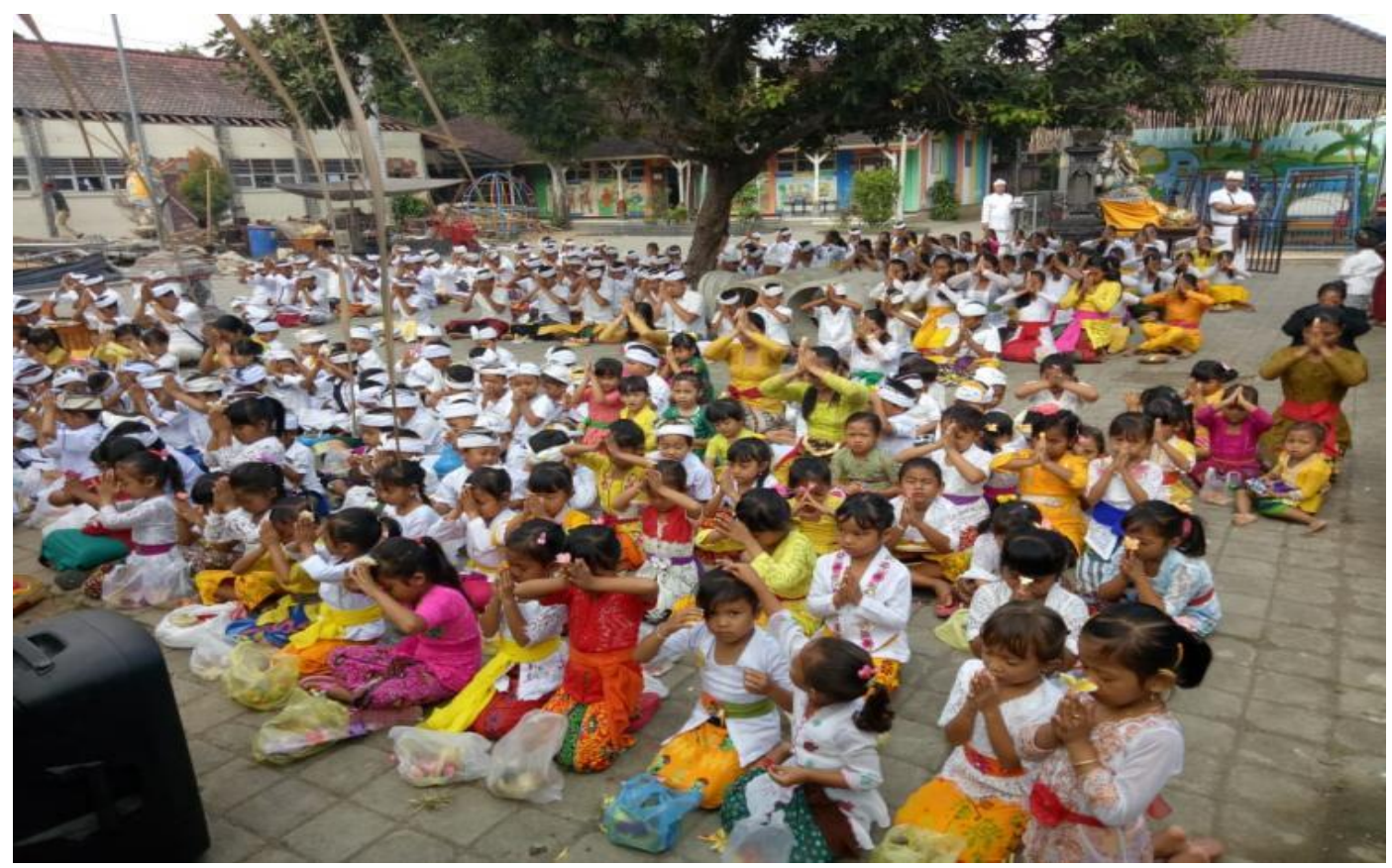

Figure 1 Praying Together Celebrates Saraswati Day at SMP Swadhyaya Penarungan (Source : https://images.app.goo.gl/sWWsUQ1tCQNFhv5a6)

Therefore, life in the family should also be developed in harmony with the atmosphere of the school as has been stated above. Communication between family members should be open and based on sincere affection. As parents at home must always provide the best encouragement to their children to achieve the best under the abilities of each child, and the opportunity to work together sincerely needs to be a habit in the family. Thus, children will use noncontradictory character value references when at school and when staying at home, in their respective family environments.

Education is a conscious and systematic effort to develop students' potential (das sollen) the education implementation in a country is the responsibility of the state to implement it in the context of the intellectual life of the nation (Kanji, Nursalam, Nawir \& Suardi, 2020).
Education that is based on national character and culture is education that applies the principles and methodology towards the formation of national character in its students through an integrated curriculum developed in schools (Suyitno, 2012).

Teachers and parents who want to develop a positive atmosphere at school and in the family environment must be able to encourage their children to develop and express their ideas and feelings, make their own decisions, and take part in determining learning goals through their attainment procedures. The role of teachers and parents in instilling the values of character and spirituality in children at home and students at school can also regulate the classroom or family atmosphere so that children can discuss each other's problems together. Working and discussing together can provide opportunities to understand one another and provide opportunities to interact (Zuchdi, 2011). 


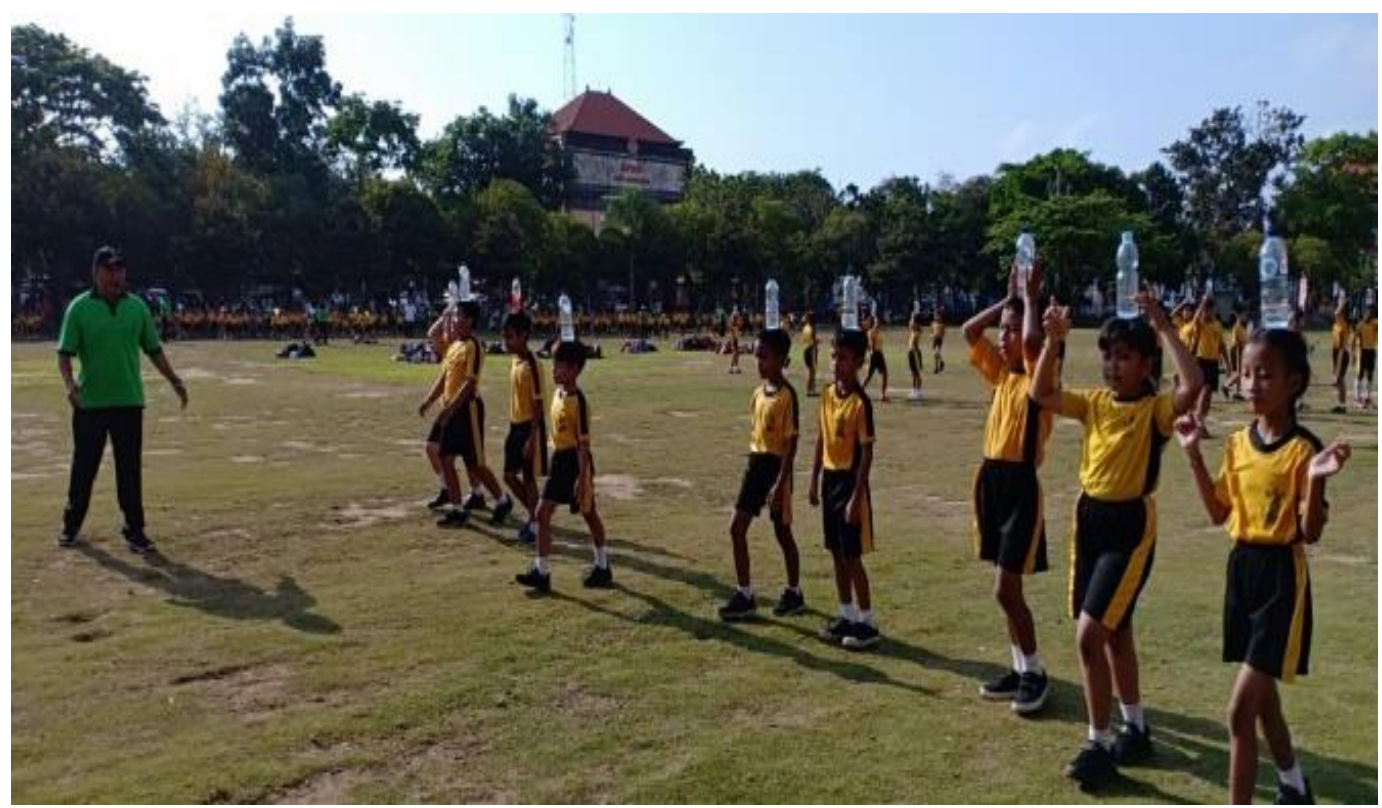

Figure 1. Middle Semester Activity I 2018

(Source : https://sd-saraswati6.sch.id/?p=1108)

To implement character education we cannot do it by only one party. When the teacher forms character values in children, while in the community he sees many values violated then there are only two possibilities, he still holds fast to the values that have been learned and expected to have a strong drive to carry out school work and assignments home and possible. So that the children will voluntarily accept and practice the positive character values that become their beliefs along with all family members. If children feel uneasy and anxious in the face of conflict or are ignored, their intellectual and emotional development will hamper their learning development. So it will cause positive character values they will ignore and negative values they will make the basis for behaving. According to Schmuck and Schmuck (Zuchdi, 2011) recommends that teachers can develop a positive classroom atmosphere, which has the following characteristics: 1) Students want the best results according to their abilities and provide mutual support; 2) Students influence each other positively; 3) Joy arises in school and a class specifically; 4) School rules are followed in an orderly manner without coercion, so they can do well the tasks; 5) Communication between school members is open and colored with close dialogue; 6) The process of working and developing together as a group is seen as suitable for learning. Positive classroom or school atmosphere as mentioned above is what can develop fundamental character values that are very necessary for the social life of students themselves. The values of these characters include the value of affection between fellow believers, the willingness to achieve the best in ways God Almighty gives that. The education environment (family, school, community) does not work alone but is a work unit. The principle of loose responsibility must be avoided. As a principle when the child is in school then it is the responsibility of the teacher. When the child violates outside the school, it is not his responsibility because they do it after school hours. Further, to achieve success giving value to students, we form the character values in ourselves. Maybe there are still teachers who remind students not to be late to school, but they are late to school. There are still teachers who remind students not to conflict with fellow students, but it involves them in conflicts with fellow educators. An education will not be effective and succeed if the educator is not educated and does not have a dimension of sincerity (Zuchdi, 2011). 


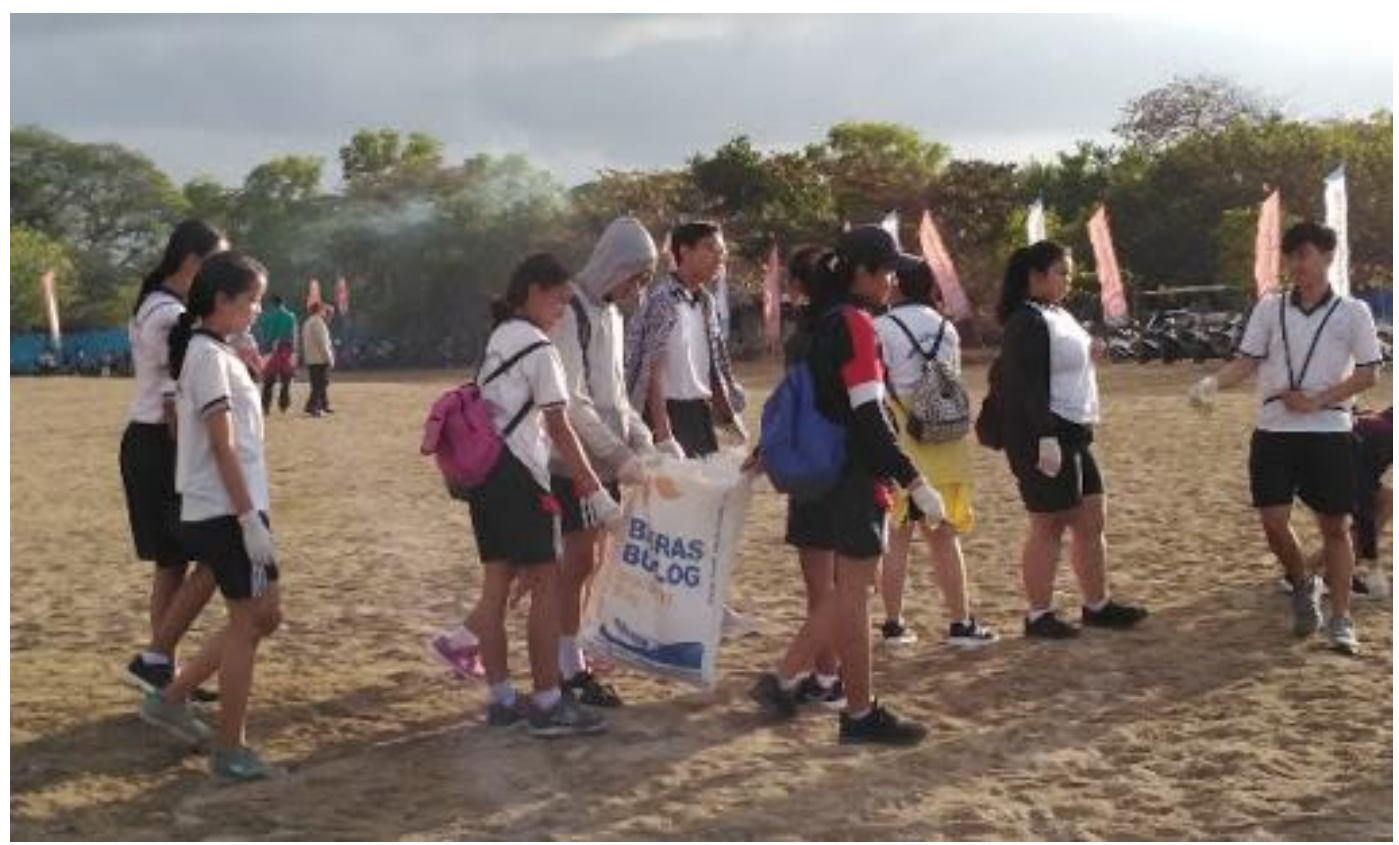

Figure 1 Welcoming the School Anniversary, Students of SMAN 2 Denpasar Hold Clean Action (Source : http://koranjuri.com/sambut-hut-sekolah-siswasman-2-denpasar-gelar-aksi-bersih-lingkungan)

To change or shape the value system in children, it requires a process and can not form these characters instantly. Therefore, both parents, teachers in schools and the wider community need patience and extra effort to shape personal character. They will later develop the country and uphold religious, moral, and social and community life rules through reflection of ethics, morals, manners. It characterizes by a strong spirit, determination, and energy with positive thoughts from optimistic attitudes. In the school environment, children experience a change in behavior. The process of change in behavior and religiosity in students is following the social and cultural values in the curriculum made by the school. The educational curriculum implemented by the teacher, one of which can function to shape the behavior and spirituality of students toward optimal adult personality. At school is the place where the transformation of the noble values of character and spirituality of students through learning or education takes place. Character education and spiritual values are the keywords of the transformation of noble values in schools. Teachers become transformers of noble values to students to become part of civilized society. Wiyani states that there are several functions of transforming noble values carried out by schools covering five dimensions, namely: 1) Education includes not only knowledge and skills but also attitudes, values, and personal sensitivity; 2) The role of social selection (including not only the granting of certificates but also the selection of employment opportunities); 3) Childcare functions; 4) Community activities (Wiyani, 2012).

So, schools have the functions of education, social role, maintenance, and social activities. Schools as a vehicle for the transformation of character values and spirituality and student knowledge will determine the style of thinking and behaving following religious norms that are believed and owned by the community. So that students' personalities will be formed according to their cultural roots and the ability to respond to changes in society. The process of character education through the concept of teaching Tri Hita Karana at school by educating students to always serve God Almighty by accustoming students to always pray (Tri sandya) before the learning process begins, always praying at the temple in school, teach students to always pray at 
their respective homes before leaving for school. By teaching devotion to God, students have an understanding that devotional service is a deep affection for God, devoted to God means students will always have a tolerant attitude towards implementing other religious worship with other school residents. We accustom them to building daily activities that reflect the embodiment of character values in building harmony between humans and God as the creator, human relations with humans and human relationship with the school environment. These relationships are manifestations of the teachings of Tri Hita Karana (Wirawan, 2011).

The approach that can be used in implementing the Tri Hita Karana teachings to build student character with four pillars, namely: (1) learning process activities; (2) daily activities in the form of school culture; (3) co-curricular and or extra-curricular activities; and (4) daily activities at home and in the community. The objectives of character education through implementing the Tri Hita Karana teaching concept are: (1) encouraging the achievement of the learning success of participants and to mature students to be sensitive to the perfect moral values, and balanced between intellectual, emotional, and spiritual intelligence; (2) educators/teachers are expected to be primary effects, which can give and make themselves role models for school environments, especially for students/students; (3) can create Indonesian people who are wholly, namely people who believe in and fear God Almighty, have good morals, have a high responsibility in life; (4) to grow and develop the basic abilities of students to always think smart, be religious, behave nobly, love fellow human beings, be moral, care for the environment, do something good beneficial to oneself, family, and society, building multicultural life of the nation, building an intelligent, and noble civilization, building attitudes of citizens who love peace, creative, independent, and living side by side with other nations; and (5) to form humans who have noble personalities and have a high character, always live in harmony with fellow humans and with nature. Every human being ultimately gets physical and spiritual happiness. With the noble character of every effort and activity carried out.

\section{CONCLUSION}

Based on the results of the analysis of the Tri Hita Karana concept as a foundation for education to build the character of students in the school, it can be summarized as follows: Collaboration between school and family needs to be increased so that there are no contradictions or inconsistencies between the values that children in schools must hold and those they must follow in the family environment or in the community where the child is. If there is a conflict of values, children may feel confused so they do not have a handle on the values that become a reference in behaving. As a result, they cannot control themselves in facing negative influences from the surrounding environment. The objectives of character education through implementing the Tri Hita Karana teaching concept are: (1) encouraging the achievement of students' learning success and maturing students so they have a sensitivity to perfect moral values, and balanced between intellectual, emotional, and spiritual intelligence; (2) educators/teachers are expected to be primary effects, which can give and make themselves role models for all school environments, especially for students; (3) can create Indonesian people who are wholly, namely people who believe in and fear God Almighty, have good morals, have a high responsibility in running this life; (4) to fostering the basic abilities of students to always think smart, be religious, behave nobly, love fellow human beings, be moral, care for the environment, do something good beneficial to oneself, family, and society, building a multicultural nation's life, building intelligent, noble civilized civilization, building attitudes of citizens who love peace, creativity, independence, and coexist with other nations; and (5) to form a human who has a noble personality and has a high 
character, always living in harmony with fellow humans, with the natural surroundings and the harmony of human relations with its creator, namely God Almighty. So that every human being ultimately gets physical and spiritual happiness.

\section{REFERENCE}

Dewi Sartika, Lianda and Joebagyo, Hermanu and Susanto, Susanto (2020) CATUR GURU: REAKTUALISASI NILAI-NILAI DALAM KESUSASTERAAN HINDU UNTUK PEMBELAJARAN SEJARAH LOKAL. In: seminar nasional dan temu alumni HMPS 2019, 12 oktober 2019, FIS UNY Yogyakarta

Donder, I. K. (2007). Kosmologi Hindu: Penciptaan, Pemeliharaan, dan Peleburan Serta Penciptaan Kembali Alam Semesta. Surabaya: Paramita

Kanji, H., Nursalam, N., Nawir, M., \& Suardi, S. (2020). Supporting and Inhibiting Factors of Character Education in Learning Social Studies at Primary Schools. JED (Journal of Etika Demokrasi), 5(1), 1-14.

Rosmilawati, I., \& Darmawan, D. (2019). Getting Back on Education: What's Learning Look Like in Indonesian Prison High School?

Salim, E. (1986). Pembangunan berwawasan lingkungan. Jakarta: Lembaga Penelitian, Pendidikan dan Penerangan Ekonomi dan Sosial.
Sarwono, S. (1995). Psikologi Lingkungan. Jakarta: Grasindo.

Sukarma, I. W. (2016). Tri Hita Karana: Theoretical Basic of Moral Hindu. International Journal of Linguistics, Literature and Culture, 2(3), 84. https://doi.org/10.21744/ijllc.v2i3.230

Sukmaningrum, P. S., \& Faizah, S. I. (2019). Strategi Penguatan Ekonomi Orang Tua pada Keluarga Anak Jalanan di Surabaya. Jurnal Sosial Humaniora, 12(2), 66-76.

Suyitno, I. (2012). Pengembangan Pendidikan Karakter Dan Budaya Bangsa Berwawasan Kearifan Lokal. Jurnal Pendidikan Karakter, (1). https://doi.org/10.21831/jpk.v0i1.1307

Wiana, I. K. (2007). Tri Hita Karana Menurut konsep Hindu. Surabaya: Paramita.

Wirawan. (2011). Evaluasi Teori Model Standar Aplikasi dan Profesi, Contoh Aplikasi Evaluasi Program: Pengembangan Sumber Daya Manusia, Program Nasional Pemberdayaan Masyarakat (PNPM) Mandiri Pedesaan, Kurikulum, Perpustakaan, dan Buku Tes. Jakarta: Raja Grafindo Persada.

Wiyani, A. (2012). Save Our Children From School Bullying. Yogyakarta: Ar-Ruzz Media.

Zuchdi, D. (2011). Pendidikan Karakter dalam perpektif Teori dan Praktik. Yogyakarta: UNY Press. 